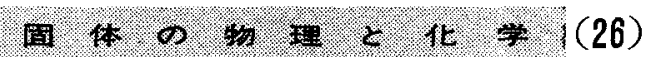

\section{化学的展望（その 2)固体材料の開発}

前回 [本誌: 30，838［1962］に固体問題の全貌とそれ にとくに重要な関係のある固体の高次構造および高次現 象について述べた．今回は固体問題のもう一つの重要な 問題として，まず結晶体と非晶体が物性および現象にお いて著しい齐立を示すことを述べる。つぎに前回のまえ がきに述べた固体問題に対する三つのアプローチ，すな わち物理的，化学的，技術的 (工学的) の中の化学㭙 プローチにつき，固体材料母体の関発，物性の開発衫上 び固体材料の製造，精製，樎制御などの開発につい て，抢毛物の考光方や方針を中心に述べてみたい，半 導体之か磁性体など個々の問題についてはすでに多くが 記述されており，また本稿では全部の物性を扱うので一 つ一つの問題について「精密科学的」に詳しく記述でき ないことをあらかじめご諒承いただきたい，

\section{4 結晶体亡非晶体（とくに高分子）上の対決}

結晶体と非晶体とにはよく知られるように表 3 に示す ような差異がある（比較のため液体もあげておいた） この多くは自明であるが，つぎの 2 点はとくに強調する 必要がある。

第一は表 3 の最下部仁記された流動成分である。液体 や非晶体ではその媒体の中を流動（何かの駆動力に忘じ て滑かに，または周囲と衝突しつつ，あるいは位置交換 をくり返元しつつ移動)する成分が，主として原子，分 子，イオンといった質量の大きい実体である。これに対 し結晶体内ではてれらも可能であるが，高温でないかぎ りあまり活発ではないむむしろ電子や正孔の上うな軽成 分や, phonon, exciton, 転位, domain wall, magnon などのような局所的な秩序や乱れまた湦子化の結果生 じた“pattern”が流動することが多い。この結果，結

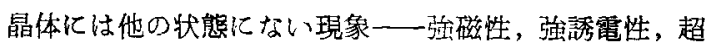
電導，光電導など——示している．そしててれらが近 代のいわゆるエレクトロニクスの源上なっていることは 周知のとおりである。

第 2 の点は非晶体，之くに高分子が固体 electronics に見るような機構を欠いているにもかかわらず，機能的 にはきわめて興味深い，固体 electronicsをはるかに上 回る物每界を形成している点である，換言すれば近年

* 東京大学物性研究所（東京都港区森布新竜土町）
牧島 象 二*

表 3 結晶体と非晶体の差

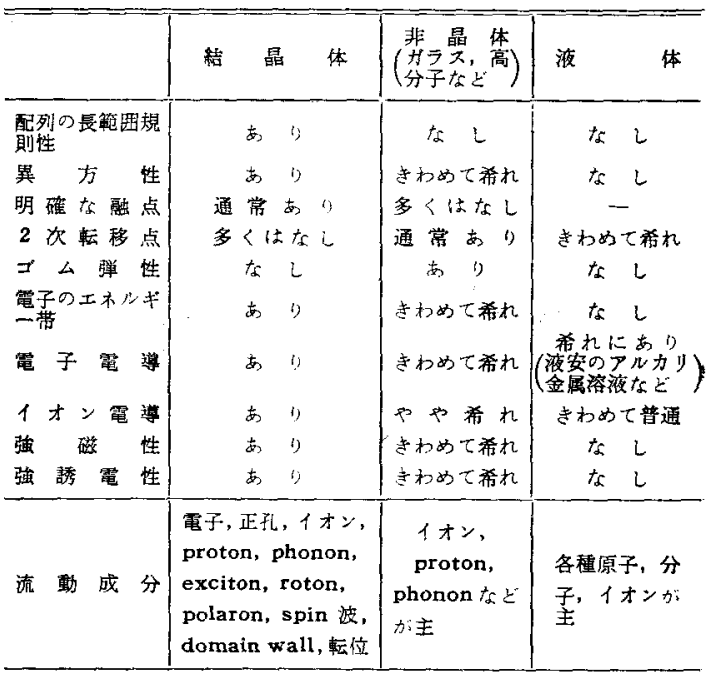

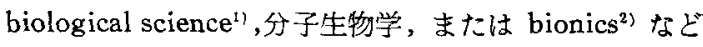
とよばれる生命を物質科学的们解明する学問，および生 物機能の工学的応用である。生体を情報処理系として見 れば, 脳, 眼, 皮虑その他の感覚器官における情報の検 知, 発生, 伝達, 眝蔵 (記憶)などにおける神経細胞の 機能は現代の固体 electronics よりはるがすぐれてい る・また生体を代謝体系としてみるとき，呼吸，消化な どの化学変化に関与するビタミン，ホルモンなどの示す 醇素的触媒作用や，美事に pattern を規制した生合成過 程は現代合成化学のはるかに及ばねとてろである、また 筋肉の収縮を骨子とする生体の運動は高い効率で化学工 ネルギーを直接に機楖エネルギーに変換するものとして 他の追従を許さない(こ机を“軟らかい機珹”とか “mecanochemistry”などこ呼んでいる).さらに生物の 一大特長である增殖過程（再生産過程）にわいて遗伝情 報をつかさどるといわれる核酸の作用など鷩くべき機能 であるが，近年急に関心を呼ぶようになり，少しづつ系 ロが見出されてきたようである。

ここで筆者があえて“対沠”というどざつい芦葉を使 ったわけは，結晶体，とくに単純なゲルマニウムとかシ リコンなどと複雑な高分子の形成する世界がまったく対 立する，きわめて注目すべき物筫界を形成しているため 
である、結晶質の支配する固体エレクトロニクスの世界 では母体は組成のきわめて単純な物賢で，搆造は規則的 な配列を示し，その中で電子とか phonon, spin wave などの軽成分や pattern 功流動成分として活躍し，とれ を強く左右するものとして構造欠陷, 超構造など高次構 造がある・てれに対し高分子の支配する生物界では構成 要素はきわめて複雑多㞳な高分子であるが，全体として は長範囲規則性はなく，お互いはりるく結合している。 流動成分はイオンとか分子で重く，個々の高分子の構造 特異性は重大であるが, 全体としての高次構造に相当す るものは考えにくい，妙なたとえであるが，前者は単純 な個人が強い全体主義で統制された集団を造り，その中 で特殊の指導者が特殊のシステムを案出して特長ある成 果をあげている，といった形である，後者は高度に摩か れた，かつ多種多様な能力を持つ個人が，きわめてゆる い結びつきで集団を造り，特定の指導者や組織なしに素 晴らしい成果をあげている*.いわば東西两世界の対比を そのまま現わしているようである。これはばかげた比較 のようであるが，多要素の集団が単なる統計的乱雑なも のでなく，ある機能をそなえるために必要な 2 つ可能 性として科学的, 論理的な根拠があると思われる。とも あれ固体科学を考えるにあたってはたんに band theory などだけにげんわく（矓惑)されることなく，高分子の 世界もいつも念頭におくべきであらう。

\section{5 固体材料の開発}

近代の科学，技術に㧍いては物兵，工ネルギ一，情報 の 3 つが 3 本の柱ともいえる．この順に後のものほど抽 象化してくるが，また時代の進歩とともにこの順に比重 も增してきている。しかしこれら3要素の発生, 伝達, 貯蔵，検出，変換などの具体的操作にはかならず物䐝， とくに固体材料が関係する。

固体材料開発の化学的アプローチとしては，前回のま えがきにも述べたように，1）何か新しい物性を開発す る，2）何か新しい物質母体を探索する，3）材料の製造 法，精製法，久楩の制御法などに新機軸を出す，の3 方 向がある、そしててれらにも条件をなる心゙く単純化し， 事柄の解析を深めてゆくやり方 (精密科学) と, 条件を なるべく拡大し諸現象を総合的に関連させつつ新領域を 㹡げてゆく行き方 (開発科学) 々ある, 前者の例は周知 のゲルマニウム，シリコンに関する研究でてれによって 得た㜆大な知㫕が固体科学にほとんど革命をもたらした といっても過言ではない，近頃はこれにつつくものとし て GaAs など III-V 族化合物や，別の角度から異方性 の著しい黑鉛 ${ }^{19)}$ やビスマス ${ }^{27}$ に関心が向けられてきた ようである・これに反し後者の行き方はまだはなはだ奻

\footnotetext{
*たたし「生命」という実体を掘友にくい共通目的のためにはすべての
} 部分がきわめて强力な一政協力を示している。
稚な段階で，物好きなが散発的に試みているといった 感じが深い，乙の方面にも一貫した逞ましい方法論があ るべきだと思うが今のところ見つからない，以下には上 述の3つの方向から化学的アプローチを試みるが，筆者 の意图はいま述べた方法論の試案ともいうべきものを提 案することにある・はなはだ不完全とは思われるがこの 点をだ汲み取り載ければ幸である。

\section{6 物性の開発一化学的アプローチ（その 1)}

物性の開発には 2 方面がある。第一は従来にない新し い物性上の要求を出し, それをみたす物質をさがすこと である、第二は徥来知られて物性の応用法を搪大し，そ れに見合うように改善向上された物性をもつ物質を開発 するととである.たとえば熱電気現象は古くから知られ ていたが，てれを電子冷凍や熱電気発電に利用しようと いう試みは近年になって盛んになった。そしてとの目的 にかなうものとして $\mathrm{Bi}_{2} \mathrm{Te}_{3}-\mathrm{Sb}_{2} \mathrm{Te}_{3}$ 系とか金属ケイ化 物などが開発された。また，超電尊現象を強い磁場の発 生, 記憶素子, 増幅用材料などに使う考えは古くからあ ったが，臨界温度わよび臨界磁場の高い材料とその加工 法 $\left(\mathrm{Nb}_{3} \mathrm{Sn}\right.$ を始め類似の化合物半導体) が開発されて 近年はじめて実用に近ずいてきた。との第二の行き方は むしろ技街的アプローチに属するので，ここには第一の 立場に立って考えてゆくこよにする。

\section{B.1 物性開発の方法淪}

物性には電気的，機械的というような普通の分け方が あるが、つぎのよのな別の見方もできる。

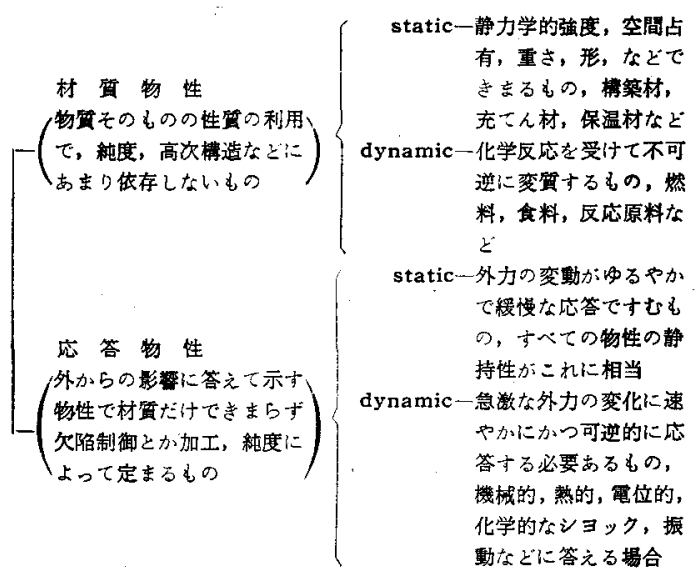

このような物性の分類からみると新しい燃料，食料， 構築材料，耐熱材といった種類の物質は物質の基本的性 垻一一物質母体の個些一で定まることが多い，てれに 対し外加ら電磁場, 力学的振動, 光などを与えたときに 示す物性はもっと芸が細かくて情報処理などに結びつい たより高次の物性である。前者を便宜上材質物性 (material properties), 後者を応答物性 (response properties) と呼んでおく、応答物性は広い意味での外力を $F$ ，それ 
に対する応答として現われる性質を $R$ とすれば，一般 k,

$$
R=\left(\tau_{1}\right) F+\left(\tau_{2}\right) F^{2}+\cdots \cdots
$$

のように展開してよいであろうＦの1次の項で近似で きるときは現象はいわゆる“linear”で，2次以上の項

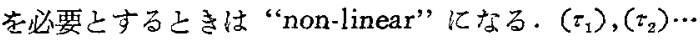
は外力之忘答とを関係ずける相関係数で，導電率，透磁 率，吸光係数，弾性係数などとよばれる物性定数はすべ $\tau$ linear 亿近似したときの $\left(\tau_{1}\right)$ 飞相当する，外力 $F$ も応答 $R$ も scalar 量であることは少なく，また固体は 多くは等方性でないから $\left(\tau_{1}\right)$ も scalar 量であることは 希れで，2次か，それ以上の高次のテンソルである. F も $R$ もともにベクトル量である電気伝導, 誘電分極, 磁気分極，熱伝尊などにみられる尊電率，誘電率，透磁 率，熱伝尊率などの物性値は一番簡単な部類で 2 次の对 称テンソルである. scalar として扱われるてれらの值は その主値の平均檤と考えるべきものである。无る璉の現 象，た之觉ば強誘電分極，強磁性分極，光弾性などは上 記の $\left(\tau_{1}\right)$ がさに同一または別種の外力の影響で変化す る場合である。これらの場合は前式の $\left(\tau_{2}\right)$ 以下が関係 したり，別の physics が関係して一層複雑になる・との ときの物性值，たと究ば䭂和分極，保磁力，光弾性定数 なぞを複合物性定数，乙れに対し単純な $\left(\tau_{1}\right)$ に相当す るものを単純物性定数之呼んでおくどちらも温度や圧 力，物䁈の化学組成で変化する．また外力が振動的な場 合は物性值は振動数依存性を示す．これらの依存性をま とめて物烧定数の変動特性之呼ぼう。ささらに応答の速や かさや緩和の速さ，すなわち時定数が問題となることが あり，これらを物性定数の時間特性と呼ぼう.

物性，之くに応答物性の開発にあたっては物性定数お よびその変動特性と時間特性に着目するのが便利であ る、そしてつぎの方針で新物性を探すべきである。

1）物性值の極度に大きいものまたは小さいもの，

2) 物性值の变動係数（温度係数,圧力係数,周波数依 存性などの0のもの，正または負で著しく大きいもの．

3）物性值の時定数の之くに小さいものまたは大きい もの.

4）極低温，極高温，超高圧などの極端な条件下また は放射線の照射下で物性定数がぞうなるかを調べる。

5）大形ブロック，微粉末，薄膜，でく細い線などに したら物性值がどう変わるか，また変わらなくてもこれ を使用したら寸法效果がどのように現われるか。

6）物質系の組み合わせ汇よって見掛け上の物性值の 改善をはかる。

7）固溶体または置換効果によって物性値を改善す る.

8） 2 つ以上の特長のある物性を併有する新物軹を探 す.
9）従来相容れないと思わ扎る2つの物性を両立させ る(たとえば透明な電子電導体，プラステックな強磁性 体など)。

10）従来かならず相伴うと思わ机る2 性質を引き離す (たと元ば導電率が高くて熱伝導率の低いもの，有機物 で著しく耐熱性のるのなど〉。

11）韭平衡または準安定状態にある物質系の利用.

12) non-linear な現象の利用.

13）全く新しい物性の発見（たとえば発見当初の超電 導, 超流動, $p n$ 接合, メーザ一作用など).

そこで各論的問題にはいる前に力学的性實とか電気的 性質ふどあり以下の分け方にしたがって，どんな物性傎 が問題となるかを一覧表にしておく。

\section{幾何学的性質}

すべて材質物性：比重，分子容，結晶構造，X線回折 像，異方性

\section{力学的性質}

村翼物性：硬さ，寻うさ，粘ばさ

単純物性：圧縮率，弾性率，音速，弾性インピーダン ス

複合物性：塑性変形，内部摩擦，粘弾性，弾性ヒステ リシス，加工硬化，疲労，破壊

変動特性：上記物性の温度係数，濃度係数，補合物性 の時定数（周波数効果，緩和効果など）

\section{熱的性質}

材質物性：融点, 軟化点, 各種転移点, 耐熱性, 熱容 量

単純物性：比熱，熱伝幥率，熱起張率

複合物性: Joule 効果

変動特性：上記諸物性の温度係数，圧力係数など

\section{需気的性質}

村覧物性：金属性，半導性，絶縁性，自発分極，パイ 口電気 (焦電性)

単純物性：導電率，誘電率，熱電気諸現象，電子放射 能

複合物性 : 圧電率, 唉誘電性とヒステリシス，超電導 性

変動特性：上記諸性質の温度係数, 圧力係数, 周波数 特性，添加物効果，寸法効果

\section{磁気的性嵮}

材賈物性：反磁性，常磁性，強磁性，反强磁性，フ工 リ磁性，自登磁化，磁気異方性

単純物性：透磁率，帯磁率

複合物性：各種出磁性特性，磁気ひずみ，磁気異方 性定数, 磁気緩和

変動特性：上記諸特性の 温度，圧力係数，周波数効 果, 添加物および寸法效果

\section{光学的性兵}


材䫓物性：透明性，色，多色性，複屈折性，旋光性， ケイリン光性，娍光性，熱変色性

単純物性：屆折率, 吸収率, 旋光度

複合物性 : 分散率, 光電導性, 光弾性, Faraday 効

果, Kerr 効果, Cotton-Mouton 効果

変動特性：上記諸性質の温度係数, 圧力缧数, 波長依

存性，および縦効果々横効果

\section{化学的質性}

すべて材實物性：溶解性，吸湿性，酸・アルカリ性，

酸化・還元性, 極性, 電離性, 可然性, 爆発性, 反

応性，耐食性，耐光性，耐熱性，触媒作用など

\section{界面的性啠}

下記のすべての性質が材質物性でも応答物性でもな い，材質，表面構造偟よる高次かつ多くは不可逆な物性 である。

摩擦，吸着，双れ，接触角，界面張力，摩擦電気，接

触電位差，仕事関数，電子放射，接触整流， $\zeta$ 電位

\section{核的性質}

材質物性：質量数，核スピン，核 4 重極，壊変特性

（半減期，崩壊の型式とエネルギー）中性子および

核反応の断面積など

単純物性: 核磁気諸効果, Mössbauer 効果など

\section{生物的性骈}

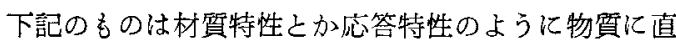
結した性質でなく，物質系が多数に組み合わさって造り 出した機能または現象（高次でしかもマクロな）であ る。知敩, 運動, 代謝, 適応, 增殖, 遗伝, 感情, 判 断，創造など。

以上大分長々之述べたが，化学的性質以下が大分様子 が異なるととにお気付き願えれば幸いである、材質物性 や応答性の上うな（固体）材料任直結した原料的な物 生汃ら，一歩を進めて solid circuit のような active element（前回ま学がき参照）を組み上げ，さらに生物 機能を目標として物性開発の領域を拡げることを念願と すべきである。

以上自己流ではあるが物性の性格分析之開発の方法論 を述べた次第で，つぎに少し個別的に考えてみよう。

\section{2 既存物性の拡大}

既存材料を応用毛含めて通常の分類化したがって概観 し，その将来性について考察してみ上う。

6.2.1 導電材料および半導体 半導体には $\mathrm{Ge}, \mathrm{Si}$, $\mathrm{ZnS}, \mathrm{Se}, \mathrm{Cu}_{2} \mathrm{O}$ のような “drift” 型と, $\mathrm{NiO}, \mathrm{Fe}_{3} \mathrm{O}_{4}$, $\mathrm{CuO}, \mathrm{FeS}_{2}, \mathrm{TiC}$, 電導ガラスの上うな“hopping”型 と2種類あるととをまずはっきり認識しなければならな い. 多くの有機半導体，タングステンブロンズ, $\mathrm{CuFeS}_{2}$ などはこの中間型と教元られる。抵抗体, diode, 熱電物 質としてはどららの型でもよいが，トランジスタ，光電 導体，ケイ光体などは現在のところdrift 型仅限られ，
磁性体，超妘導体，触媒などは hopping 型に限られる てとを注意する必要がある・するとこの中閶型の物質は 両者を併有することが予想され興味ある領域である。

今後の問題としては, drift 型半導体では, (一寸妙な 表現げが)carrier の運動空問の拡大と carrier の運動の 拡大につきると思う。運動空間の拡大と注， band gap， band の構造や異方性，band の中での carrier の易動 度や有効質量，band 内での carrier と phonon との作 用などを改善することで，おもに“intrinsic”な性質に 関係している， carrier の運動は carrier の供給源およ びそのトラップ，再結合中心などになる activator，不純 物，ひずみなどの改善と制御である。ダイヤモンド, $\mathrm{SiC}, \mathrm{BeO}, \mathrm{MgO}, \mathrm{Al}_{2} \mathrm{O}_{3}, \mathrm{BN}$ など band gap が大きく て Debye 温度の高い母体をうまく半導体化すれば，耐 熱性，逆耐圧が高い，格子振動の影響が少ない，などの ため新しい用途が考光られる。たとえば熱電子放射用耐 熱半導体, photoinjection 用の半導体, 固体プラズマや interband transition を利用する半導体など。逆に重い 元素の化合物で band gap の狭いものを適当泠して使 うととにより, 感度の高い熱電物質, 赤外検出罚, 高出 カのトランジスタなどが考光られる・レーザ（光メーザ） とくに半導体レーザの技術が急速化進歩しつつある現 在，また高周波 switching にある限界を感ずる現在，電 気的信号をすべて光でおきがるような感光性および発 光性半導体の開発が今後の重要問題であろう.

超電導体化ついては後们例示するように，遷移金風お よび希土類を含む金属間化合物または半導体が強く関心 をもたれてきた。とれらは「硬い」超電導体（hard

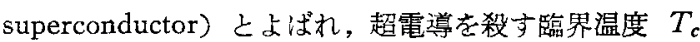
および臨界磁場の值が高く，実用上はなはだ大切であ る・磁珄と深い関係があるので，その方関連させて盛 ん任究されている. 非超電導元素加らる多数の超電導 化合物を生じ，重い元素を含むものが臨界温度 $T_{c}$ が低 いとは限らない，現在はまだ理論的予言のできる段階に はほぞ遠いが，多くの経験法則は出されている・たと光 ば Matthias ${ }^{32}$ によれば 全価電子数を全原子数で割った 比 $R$ 之躁界温度 $T_{c}$ の関係みる之， $R=6$ 亿鋭い極少 があり，てれを杜さんで $R \leqq 5$ と 7 付近保 $T_{c}$ の極大 がある。たと光ば $\mathrm{Nb}_{3} \mathrm{Sn}\left(T_{c}=17.5^{\circ} \mathrm{K}, R \div 4.8\right), \mathrm{V}_{3} \mathrm{Si}$ $\left(17.1^{\circ} \mathrm{K}, R \div 4.8\right), \mathrm{NbN}\left(14.7^{\circ} \mathrm{K}, R=5\right)$ である. 今後 は 3 元以上の多元合金や析出相などをもつ不均望合金を 研究すべきであろう。なぜなら，超電導現象山転位その

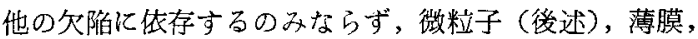
2 種物質の接触によって著しい影響を受けるからであ る.

6.2.2 磁性体 $\mathrm{KS}, \mathrm{MK}$ 磁石鋼や OP 磁石を産ん だ日本は磁性体の研究はとくに盛んで，金属系やフェラ イトについては余地は少ない上うに感ぜられる．実用的 
な要求からは switching のきわすて早いもの，ヒステ リシスの角形性の著しいるの，などが新しいものである う。学術的興咮からは希土類 ${ }^{4}$ や $\mathrm{Cr}^{5}$ などのラセン形 にスピンの配列したもの，希薄合金の磁性，非遷移金属 より強磁性化合物の製造（たと光ば $\mathrm{ZrZn}_{2}^{6}$ )，薄膜およ び微粉末の磁性，磁性超電導体（後述）などがある。 後の問題としては，材料的には各種遷移金属化合物，希 土類を含む合金抢よび化合物，フェライトに代って酸素 の代わりに S, Se, Te を含声磁性半導体などが 開発の 余地があうう。有機物やガラスの強磁狌体，強磁性体で 光電導性やヶイ光性の物筫の発見なども興味ある問題で ある.各種の格子欠陌之磁化特性（磁気緩和子含吉），磁 性体の光物性的研究なども今後の興味ある問題である。

6.2.3 誘電体 強誘電体は戦後代新しいるのが 40 種以上開発され，引き続き発見されつつあるが，その中 亿は硫安，チ才尿素， $\mathrm{KNO}_{3}$ のよう飞きわめて身近加な 物筫まで含まれている，大別すると水素結合をもつもの (ロッシェル㙁, KDP, GASH, TGS など)，七ラミッ ク系のもの $\left(\mathrm{BaTiO}_{3}, \mathrm{PbZrO}_{3}, \mathrm{KNbO}_{3} な と ゙\right)$, 内部回 転基をもつ軟らかい結晶 $\left(\mathrm{NaNO}_{2}, \mathrm{KNO}_{3}\right.$ など)に分け られる。これらに化学結合, 結晶学的特長をはじ物性 的にもかなり異なった系統であるのに，強い自発分極を 生ずる点で一致している，强誘電性の真因は，磁性比比 べるとはるかにわかっていないが，この辺に共通因子を 求めるのが解决の鍵となるのではないかと思われる。空 閒的任固定された自発分極（たとえばパイ口電気性を持 つ電気石など）では外部電場によって任意の方向に向き がるわけにめかずしたがって強誘電体とはなりえ ない，結晶学的予想传反してりしろ対称性が高く，外部 電場の影響でたやすく分極を発生するようなるのでなけ ればなら双、 $\mathrm{NaNO}_{2}$ などで法結晶が軟らかく，屈曲し た $\mathrm{NO}_{2}$ 基は極性をつので，てれが電場によって内部 回転を行なえぱ今の目的以かなうと思われる、筆者らは $\mathrm{NaNO}_{2}$ と $\mathrm{AgNO}_{2}$ とを比べ, $\mathrm{AgNO}_{2}$ 怡 $\mathrm{Ag}$ と $\mathrm{NO}_{2}$ の間に強い等極性の結合のあるととを光物性的につきと めたそそのために $\mathrm{AgNO}_{2}$ は強䛣電体でないととを予備

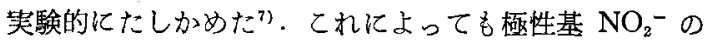
内部回転が強誘電性の原因であるととは確からしく，と のグループは発芫は一番新しいが，強誘電機構は一番早 く解明されるのではないかと思う.今後の問題としては 水素結合を行なう結晶をもっと広くさがすとを perovskite 型以外の高対称の複酸化物, 複硫化物などをさがす 乙と, $\mathrm{SCN}^{-}, \mathrm{CN}^{-}, \mathrm{BO}_{2}^{-}, \mathrm{ClO}_{2}^{-}, \mathrm{CO}_{3}^{2-}$ などの球から はずれたイオンを含む低融点化合物をさがすこと，など が考えられる。

6.2.4 光物性材料 ケイ光灯, エレクトロルミネセ ンス (EL), シンチレーションなどのケイ光体，ビディ コン, 電子写真などの光電導体, クリスタルカウンタ用
結晶，撮像管や電子堌幅管用の光電子放射材料などには

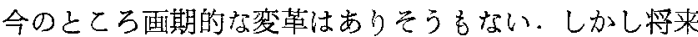
導線を流れる電流や空間を伝わる電波の代和りに光を使 うととを考光る之, 光電導, $\mathrm{EL}$, band 閵の再結合によ る発光などの利用がもっと考朰れてよいのではないか と思う.乙れらの目的汇は複化合物, 有機物, ガラス, プラスチックスのケイ光体，とくに大形単結晶ケイ光体 や光電導体の研究が必要であうう. 今のところ光物性領 域で一番話題をにぎわしているのはレーザ㫙 (Laser, 光 メーザ）であろう・ルビーレーザタはすで市販されて おり， $\mathrm{CaF}_{2} 飞 \mathrm{Sm}^{2+10)}, \mathrm{U}^{3+}$ などを加光たもの， $\mathrm{Nd}$ ガ ラスなども実用に近い，今後はレーザビームの波長の変 更 (もっ之短波まで)，高利得にするための励起 (pumping）効率の上昇，大形高出力にた光る cavity 材料の研 究などが問題であらう、レーザ用発光体として希上類は 余すてと鉦く研究されているが，てれに励起光を有效に

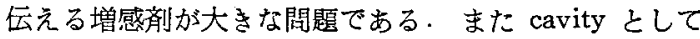
ルビーや $\mathrm{CaF}_{2}$ のひずみの少ない大形単結晶は価格が高 いので，がラスとかプラスチックス（または液体）が考 えら机る.との目的のための試みとして近頃アセチルア セトン誘導体と希土類とのキレート化合物を用い，有機 溶媒またはプラスチックスに埋めたものが試みられてい $る^{\left.{ }^{11}\right)}$ キレートの錯結合を通して有機分子が吸收した励 起エネルギーが有効に希土類に云えられる。

\section{3 寸法效果の利用}

（大形ブロック，薄膜，細線，微粒子など）

大形ブロックはその均一性，定まった方向性なぞを利 用する場合で取りたてていうととはない，問題は安価に 均一大形ブロックを造る方法にある。乙れに反し薄膜， 微粒子，細楾などには多くの新しい問題がある.パーマ 口イなどの磁性金属の薄膜 ${ }^{12\}}$ 放，その高い磁気異方性 から優秀な記憶素子になると上は有名な事夷である，光 学材料の薄膜の組合合わせが，反射防止膜，干涉フィル タとして使われることる周知のとおりである。がラスや プラスチックスの細線が曲げるととのできる光の通路と して “fibre optics”なる新しい光学技術を生み出した こと,ナイロン糸などの表面汇記録用の $\gamma-\mathrm{Fe}_{2} \mathrm{O}_{3}$ の粉 末を凇って磁気 wire として利用するてとなどは，紐楾 とすることによって物性の本質を变えたわけではない が，実用特性は大い似変わる例である，微粉末にしてそ の寸法が mean free path, domain size, penetration depth（超電導体など）などとせり合う場合には，関係

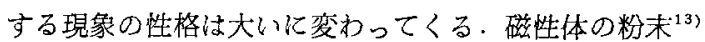
などはその著しい例である。ととに興味あるのは超電導 体で，粒秷とか膜厚がその penetration depth $\lambda\left(=10^{-6}\right.$ $\mathrm{cm}$, 表面からこの厚さだけに表層電流が流れ，それより 内部では酳場が 0 になる）亡同程度になると，超電導性 を破る磁場の強さ，いわ应臨界磁場 $H_{c}$ の值が大きな 
試料に此べてはるかに大きくなる。乙れを利用して G E. の研究室では多孔質ガラス Vycor の中に強圧で超電 递金属 $\mathrm{Hg}, \mathrm{Pb}$, In などを溶融状態で圧入したものを用 いて $100 \mathrm{~A} / \mathrm{cm}^{2}$ の電流でも超電導が破れぬため, 10 万 Gauss の超強磁場を与える超電尊磁石の製造に成功した と伝えられている位。

\section{4 組み合わせによる物性值の改善}

事がらの純粋性に立ててもろうとする研究者はてのよ うな方法を好まないらしいが，技術的にはきわめて重要 かつ興味ある方法である．また純基礎的な方面にすら大 きな貢献を示しつつある.早い話しが $p n$ 接合も組み合 わせである，また近頃話題をよんだトンネルトロン15)* は Esakidiode と同種の用途をもつのみならず，超電導 体の基本特性(フェルミ準位をはさむ小さなエネルギー 禁止带の幅）を測る有力な方法を与えている。

組み合わせによって得られる物性の多くは加成性を利 用して, 平均值とか相補效果を狙っている. 泡ゴム, 泡 ガラス, 粉末ヤ金, cermet, plastics の膜と金属膜, ガ ラスせんいで強化したポリエステル樹脂，導電性または 磁性粉末を充てんしたゴムやプラスチックス，含浸によ って不浸透性にした黒鉛，強化木材，などがこの例であ る.てれに対し，組み合わせによって組成物質にはない 新しい物性を現出する可能性もある。多首光学薄膜によ る選択的透過または反射効果， solid circuit にみるいろ いろな電子特性, 析出硬化性の鎆, ジュラルミン, ベリ リウム青銅，窒業鉱物をガラス中に析出させたガラスセ ラミックス(とれ枯茀熱性大きく，膨張係数も0または 負にすることもできる)などこれ嘱する。

\section{5 固溶体または羁換効果の利用}

てれも組み合わせ效果の1種で, 6.4 が “heterogeneousな組み合わせ”と見れば，これは“homogeneous な組み合わせ”と見るてとができよう。やはり加成的効 果と相乗的選択効果とが期待される。

固溶体によって物性を変更することは多くは加成性に よるもので $\mathrm{Si}-\mathrm{Ge}$ (半尊体) ${ }^{16)}, \mathrm{ZnS}-\mathrm{CdS}$ (ケイ光体), $\mathrm{ZnS}-\mathrm{ZnTe}$ (ケイ光体), $\mathrm{Bi}_{2} \mathrm{Te}_{3}-\mathrm{Sb}_{2} \mathrm{Te}_{3}$ (熱電物真) ${ }^{17)}$, $\mathrm{SrO}-\mathrm{BaO}$ (熱電子放射体)，( $\mathrm{K}, \mathrm{Rb}, \mathrm{Cs})_{3} \mathrm{Sb}$ (光電陰 極 ${ }^{18)}$ などはての例であろう，同位元素置換によって誘 電体のCurie 点や, 超電導体の臨界温度 $T_{c}\left(T_{c} M^{1 / n}=\right.$ const, $M$ は同仙元素の質量, $n$ は “soft” な超電導体 ではふつう 2）を変えることができ，また核物性（核ス ピン，核 4 重極，中性子の吸収断面積など）を変えるこ とができる.

混合系を開発するのに一番有力な手段は有名な原子価 制御 (valence control) の方法てある。てれはフェライ トやチタン酸バリウム系誘電体などには広く使われてい

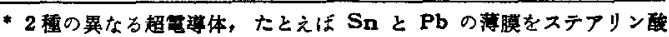

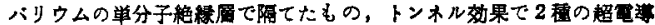
体間に電流が流れるが，加える電位美でこれを制缷できる。
る.たと䒕ば $\mathrm{BaTiO}_{3}$ で 4 価の $\mathrm{Ti} 1$ 個の代わりに $($ III + V $) / 2,($ II + VI $) / 2,(2$ III $+\mathrm{VI}) / 3,(2 \mathrm{~V}+\mathrm{II}) / 3$ など いろいろに変えれば 1 個あたりの原子価はいずれも 4 価 となる(実例は後出)．またフェライトのかなりの部分 を占める spinel 型物質の標準組成は $M^{\mathrm{I}} M_{2} \mathrm{~m}^{\mathrm{O}} \mathrm{O}_{4}$ (いわ ゆる 2-3 スピネル)である， II +2 III(=8 価)の代わ りに $2 \mathrm{II}+\mathrm{IV}$ ，(2-4 スピネル)，2I+VI（1-6 スピネ ル), II + III'+III (2-3 逆スピネル)などでおきかえら れる。

\subsection{2 ว以上の特長ある物性の併有}

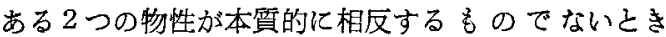
は，いろいろな組み台わせで併有させるととを考えてみ るととも有用であろう. 近頃の話題としては強誘電体で 光電導性の物質 ${ }^{19)}$ ，强誘電体で 強磁狌物質 ${ }^{20)}$ があげら れる．前者ははじめ Nitsche ${ }^{19}$ らが $M^{\text {III }} X^{\text {II }} Y$ ( $M^{\text {III }}$ : $\left.\mathrm{Sb}, \mathrm{Bi}, X^{\mathrm{II}}: \mathrm{S}, \mathrm{Se}, \mathrm{Te}, \mathrm{Y}: \mathrm{Cl}, \mathrm{Br}, \mathrm{I}\right)$ 系の物軹を研究

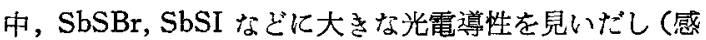
光波長域 $540 \sim 784 \mathrm{~m} \mu$ ), しか子大きな温度依存性のあ るのを知っだ、ついで $\operatorname{Kern}^{19}$ がての結晶(斜方晶系)の $\mathrm{C}$ 軸方向に $5 \mathrm{kV} / \mathrm{cm}$ の電場を加けると $630 \mathrm{~m} \mu$ の光吸 収端が $80 \AA$ も短波側にずれることを兒いだし，これが 動機となって Fatuzzo' ${ }^{19)}$ やNitsche らがC 方向著 しい強誘電性のあるととをつきとめた. SbSI の Curie 点は $22^{\circ} \mathrm{C}$, その付近での誘電率は 5 万, $0^{\circ} \mathrm{C}$ の自発分 極は $25 \mu \mathrm{Coul} / \mathrm{cm}^{2}$ で $\mathrm{BaTiO}_{3}$ とともにはなはだ大きい 部類に属する、てれに反し抗電場はわずかに $100 \mathrm{~V} / \mathrm{cm}$ $\left(0^{\circ} \mathrm{C}\right)$ で switching 時閒も十分に早い特長がある。乙 れらの諸特性の原因は 屈曲した $\mathrm{S}=\mathrm{Sb}-\mathrm{I}$ 分子が $\mathrm{a}, \mathrm{b}$ 方向に反極性的にならび，しかも $\mathrm{c}$ 方向に分子間隔が 十分近いため, 分子内の励起之か分極が，分子間の相互 作用汇影響されて発生したものらしく考えられる。後 者，すなわち強誘電体で強磁性体 ${ }^{20)}$ は 6.5 で述べた $\mathrm{BaTiO}_{3}$ の $\mathrm{Ti}^{\mathrm{N}}$ をII 価として $\mathrm{Fe}, \mathrm{Co}, \mathrm{Ni}$, III 価元 素として希土類 VI 価としては W などで置換したもの が，強誘電体であると同時にフェリ磁性体，反強磁性体 となりうるととが知られた。たとえば Fang ら $\left(\mathrm{Ba}_{6-2 x} R_{2 x}\right)\left(\mathrm{Fe}_{1+x} \mathrm{IINb}_{8-x}\right) \mathrm{O}_{30}$ などをあげている.た

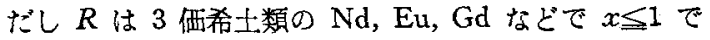
ある。

半導体で磁性体 (フェライトなど), 半導体でケイ光 体 (CdS, Si, GaAs など)，などは数多く知られている が，強磁体でケイ光性または光電導性をもつ物質はまだ 知られていない。このわけ強磁性体ではスピンのそろ った $d$ または $f$ 電子を必要とするが，光電導性または ケイ光性には外側の $s$ または $p$ 電子が励起される必要 がある.ところか励起された $s, p$ 電子のエネルギーは 速やかに $d$ または $f$ 電子の励起移行する. しかし後 者は一般に drift 型の電導性を与える可能性も少なく， 
ことに磁気的結合しているときはケイ光性を与える可能 性も少ない，しかしてれら邆移元素がある程度うすめら れて存在したりひどい異方性のために磁気的結合の方

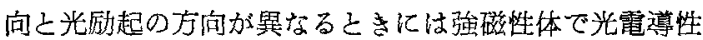
また注ケイ光性物筫をうる可能性がある゙.とくに希土類 化合物でこの可能性が大きい。

6.7 相容れぬと考えられる2 性質の併有 (A)，不可 分亡思われる諸性質の分難 $(\mathbf{B})$, 存在不能亡思 われる性質の実現 (C) など

これらはいずれも難問中の難問であるが，困難の原因 がごてにあるか深く掘り下げ，てれを実現するととが “materials science” の最大眼目の一つでなければなら ない。

まず上記表題の $\mathrm{A} ， \mathrm{~B} ， \mathrm{C}$ の部類について問題を思い つくまま拾ってみる。てれらの中で*印のものはある程 度実現されたとみて良いものである。

\section{A. 相容れないと思われる2 性買の併有}

1.*透明な電子電導体

$2 . *$ " 強磁性体

3. 有機超電導体

4. “強磁性体

5. 徒磁性超電導倈

6. " 光電導体

7. “ケ侊体

8. *強誘電性光電導体

9.*ガラス，ゴム，プラステックスで電子電遒体

10. 同上で猛磁性体

11. " 芼誘電体

12. “ 超電尊体

13.もろくない無機ガラス

14. 低温でもろくなら妨プラスチックス，ゴム

15.*耐熱性プラスキックス

B. 不可分と考えられる2性睤を引き難すこと

1.*電気の良導体で熱の不良導体

2.*電気の不良尊体で熱の良導体

3. 低屈折率, 高分散率の光学材料

4. *高屈折率，低分散率の光学材料

5. 赤外飞紫外飞专透明な物質

6. 安定で強力な爆薬

7. 不燃性有機物

\section{C. 普通では実現不可能亡考えられるもの}

1.才スミウムより此重の大きな固体

2. 此重が 1 上り小で鋼のよう治い物質

3. 無色透明な金属, 㢱磁性体

4.ヒステリシスの無い高磁性体，高誘電体

5. 臨界温度汃 $100^{\circ} \mathrm{K}$ 以上の超電導体

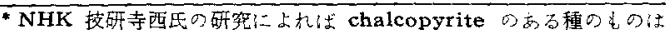
$\mathrm{Fe}$ を含九で強磁性と光䉓導性ならひに割合に大点い光電子の易動度 が認められている。
}

6. $1,000^{\circ} \mathrm{C}$ 以上代 Curie 点持つ磁性体，䛾電体 問題を提出することは勝手であるが，比重が $10^{4}$ とか $10^{-4}$ の固体，融点 100 万 ${ }^{\circ} \mathrm{C}$ の固体などいって見ても 不可能にきまっているので结意味がない，至難でも原理 的に不可能という限界のわかっていないものを取り上げ てみたわけである。号ち万ん筆者に一々名案があるわけ でないから，1〜2 の話題を紹介しておこう。

第一仙透明な電子電導体で古る。電尊が周期的坆場飞 よって生ずるものなら，1）固有の禁止带間隔が十分広 く(ての点では良い絶縁体に相当)，その中䦔にきわめ て近い donorまたは acceptor level が存在し，てれら の level そ結晶エネルギー带との間隔が赤外領域汇ある ばあい，後に述べる低抵抗の半導性ダイヤモンドなどと の例であ万う。つぎ2)結晶体でも非晶体でも，いわ ゆる hopping mechanism が可能で，しかも体が化学 結合的に安定で可視部に光吸收定もた外ばあいが孝兑ら れる・しかしてのためにはまず hopping 行なう電子 の level がかなり樑い所に苛る必要がある。つぎ hopping が可能なため以はてれを中介する結合の chain があり，hop古るためのボテンシャルの壁があまり高く ないことを要する。このためには原子洒を䱊にする陽 オン(なるべくは $\mathrm{Fe}^{2+}-\mathrm{Fe}^{3+}, \mathrm{Sn}^{2+}-\mathrm{Sn}^{4+}$ の上うな同種 イオン)功交互にならび，その中閻化やや等極結合性の 強い，半径の小さな陰仿入(たと光ば $\mathrm{O}^{2-}, \mathrm{F}^{-}, \mathrm{Cl}^{-}$, $\left.\mathrm{S}^{2-}\right)$ が介在するのがよい，乙の条件は磁気結合におけ 万超交换作用（superexchange）とよく似ているが，今 のばあい仕 $d$ または $f$ 電子を持つ必要はない。また $d$ または $f$ 電子を持つ陽イオンの酸化物，硫化物などは band gap が㹨くて着色しているので今の目的には合わ

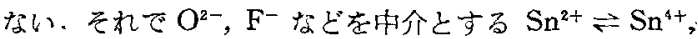
$\mathrm{In}^{2+} \rightleftarrows \mathrm{In}^{3+}, \mathrm{V}^{4+} \rightleftharpoons \mathrm{V}^{5+}, \mathrm{Sb}^{3+} \rightleftharpoons \mathrm{Sb}^{5+}, \mathrm{Ce}^{3+} \rightleftharpoons \mathrm{Ce}^{4+} ま$ たはそれらの組み合わせが， band gap の十分大きな母 体の中で出現するようふ方法が考えられる。結晶性母体 として估 $\mathrm{MgO}, \mathrm{CaO}, \mathrm{Al}_{2} \mathrm{O}_{3}, \mathrm{Ga}_{2} \mathrm{O}_{3}, \mathrm{SiO}_{2}, \mathrm{GeO}_{2}, \mathrm{SnO}_{2}$ などが考兄られるが，令のとてろはっきり成功している のは $\mathrm{SnO}_{2}^{22)}$ くらいなものである。結晶体では不利益な わけは結晶体中にはてのような hopping center がイオ ンの大きさや配列の関係上都合よくはいら奴たると思わ れる。これに対しガラス状母体や薄膜は配列が乱れてい るため, hopping center の收容能力が大きい。をして hopping 型の電尊任対しては舟体が結晶体か非晶体かは 関倸学いので, 透明電導体としてはガラス辟の上に薄層

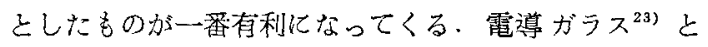
してはふつうは $\mathrm{SnO}_{2}$ 代少量の $\mathrm{Sb}$ 含むるのが造られ るが, In, Cd，および F-を含むものなど種々のものが 造られている。

ついでに以上と密接な関係のあるガラス半導体に一言 ふれておこう。無色唀明ではないが以前から Se ガラス 
および S-Se-Te 系混合ガラスが電導性のあるてとは知 られていた，近頃は，とくにりビエトにおいて， $\mathrm{As}_{2} \mathrm{~S}_{3}$, $\mathrm{As}_{2} \mathrm{Te}_{3}$ を中心とし，これにある組成範团で $\mathrm{Sb}, \mathrm{Bi}$ お よび Tl の硫化物，セレン化物，テルル化物を配合した ものが赤外透過用ならごに半導珄, 光電導性ガラスとし て研究されている ${ }^{24)}$.乙れらの物質は本来結晶において も強く着色し, 真正半導体之考学られるが，ガラスには その真正半導性が炎のまま引きつがれていると考党てよ い、るちろん非晶質ざからエネルギー帯が形成されない ので覚電率江結晶より数ケ夕低い，導電率々温度から求 めた活性化エネルギーは光昅收とほぼ一致し，真正半導 体としての band gap に対応する。また概して不純物の 効果が少なく(時に住 10\%も加えて変化がない), 対応 する結晶半導体とは全く異なった行動を示す、また，組 成の影響が結晶体と全く逆である。たとえば， $\mathrm{As}_{2} \mathrm{Se}_{3}$ $\mathrm{As}_{2} \mathrm{Te}_{3}$ 系では， $\mathrm{As}_{2} \mathrm{Te}_{3}$ の増加付対し電導度はガラスで は増加するが，結晶では減少する。またてのときガラス の軟化点は低下するが，結晶の融点は上昇する。乙れら のととから考光て, この半導性ガラスでは真正半導体に おける電導または光電導プロセスが，乱れたガラスの網 目に沿って hopping のプロセスとして行なわれている もの上考无られる・だから，ガラス構造の網目にはいる $\mathrm{Ag}, \mathrm{Pb}$ などの不純物は電導度に貢献しないが, 網目構 造の成員としてはいる $\mathrm{Ga}$ などは大きな影響を与える事 実が理解される。

つぎもう一つの例として强磁性超電導体にふれてお

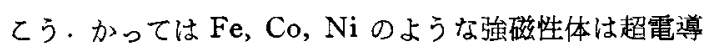
体にはなり得ないもの之され，有名は超電導に対する B.C.S. 理論 (Bardeen-Cooper-Schrieffer) でも, 強磁 性をひき礼てすような電子間の相互作用は全く考慮の外 におかれていた。しかるに近頃アメリカの Bell 研究所 の Matthias らは $\mathrm{CeRu}_{2}-\mathrm{GdRu}_{2}$ なる金属間化合物を确 究し, $\mathrm{GdRu_{2 }}$ か $69 \%$ 以上になる之超電導の臨界湿度 $T_{s}$ が強磁性のCurie 温度 $T_{c}$ より低くなり, 超電導状態 で強磁性が共存することを見いだした ${ }^{25}$ 。さらに彼らは 引きつづいて $\mathrm{Y}_{1-x} \mathrm{Gd}_{x} \mathrm{OS}_{2}$ 系につき研究し, $\mathrm{GdOs}_{2}$ が $7 \%$ 以上あれば同様に $T_{c}>T_{s}$ 上なり，雨者が共存でき るととを見いだした ${ }^{26)}$. その後同様のととが $\mathrm{LaOs}_{2}$ $\mathrm{GdOs}_{2}$ 亿ついても見いだされた。これは既存の常識を破 っただけでなく，B.C.S. 理論に重要な修正をもたらし た点で注目に值する.B.C.S. 理論では格子振動之電導 電子之の相互作用のみを考えた．今の問題から希土類の $f$ 電子がスピンをそろえて強磁性を示すととが， $s-f$ 交 换相互作用仩って電導電子 ( $s$ 電子) のスピンをそろ
える効果を生じ，超電導にはるう一つの要素，すなわち 磁性が密接に結びついていると考えるようになった。加 くて遷移金属や肴土類化合物の超電導体，いわ吼硬い 超電導体 (hard superconductor) のもついろいろの異 常性質に解決の糸口が見つかった・硬い超電導体は一般 に臨界温度わよび臨界磁場が高く，実用上重要視されて いるので,磁性と関連させて目下盛んに研究されている。 $\mathrm{Nb}_{3} \mathrm{Sn}, \mathrm{V}_{3} \mathrm{Ga}$ は有名な例で, 前者の臨界磁場は 88,000 Gauss といわれている.

(末完)

(昭 38-10-24 受理)

\section{文献}

1) たとえば小谷正雄，物理 16，340 (1961)

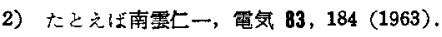

3) B.T. Matthias etal, Phys. Rev. 87, 74 (1955), 100, 626 (1955).

4) 芳田 物理 17, 2 (1962), 山田安定, 日本結晶学会誌 4, 16 (1962).

5) G. Shirane, W.J. Takei,J. Phys, Soc, Japan 17, Suppl. B-III, 35 (1962).

6) B.T. Matthias, Bozorth, Phys. Rev. 109, 604 (1958).

7）平田昌夫, 螨津 武, 林君民, 㙁谷繁雄, 牧島象二：1963 年 10 学会年会講㜑 (福岡).

8）た之えば不田光一，物理 16，606 (1961)，菅野 獍，科学 33，65 (1963).

9）たとえば三須 昭, 物性 4, 179 (1962).

10) W. Kaiser, C.G.B. Garrett, D.L. Wood, Phys. Rev. 123 , 766 (1961).

11) S.I. Weissman, J. Chem. Phys. 10, 214 (1942), N. Filipescu はか 3 名, Nature, 198, 467 (1962), E.J. Schimitschck, E.G.K. Schwarz. Nature 196, 832 (1962), R.E. Whan, G. A. Grosby, J. Molecular, Spectroscopy 8, 315 (1962), N.E. Wolf, R.J. Pressley, Appl. Physics. Letters 2, 152 (1963).

12）たと立ば服部剧三，電気 83，1253 (1963).

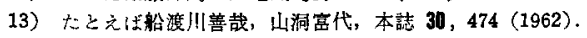

14) Electronics. 36, 18 (1963).

15) A.D. Buck, IRE 44, 482 (1956).

16）た之えば安藤桂一，物性 3，381（1962）.

17）たとえば青木昌治，菅義夫，応物 29，359 (1960)

18）たと光ば今村舞亡，J. Phys. Soc.Japan 14, 1447 (1959)，16， 1036 (1961), W.E. Spicer, J. Appl. Phys. 31, $2077(1960)$.

19) R. Nitsche, W.J. Merz, J. Phys. Chem. Solid. 21, 154 (1960), R. Kern, ibid. 23, 249 (1962), Fatuzzo, 䏡 5 名: Phys. Rev. 127, 2036 (1962).

20) た之之ば野村昭一郎, 物理 16，693 (1961).

21) P.H. Fang, R.S. Roth, J. Appl. Phys. 31, 2783 (1960).

22) J.A. Marlay, et al., J.Appl.Phys. 32, 2504 (1961).

23）たとえば E. Umblia，Glass 32，595 (1955)，中村转一, 物牲 12,583 (1957).

24) B.T. Kolomiets, T.F. Nazarove, Sovier Physics, Solid State 2, 159 (1960), I.Z. Fisher, ibid. 1, 192 (1959), A.I. Gubanov, ibid. 2, 605 (1960),3, 1694 (1961).

25) B.T. Matthias, H. Suh1, E. Corenzwit, Phys. Rev. Letters 1, 449 (1958).

26）同上著者, J. Phys, Chem, Solid 11, 346 (1959).

27）たと光ば田沼静一，物理 4，331（1963）. 